\title{
Bulgarian banking: looking for sustainability
}

\author{
Garabed Minassian
}

ABSTRACT In this work, we trace and analyze the emergence of the crisis in the Bulgarian banking system as well
as the behavior of the central bank and other macroeconomic institutions. The average annual rate of
growth in the net profits of the commercial banks for the period 2002-2008 amounted to 31.6\%, which
encouraged and accounted for the increase in credits. After 2008, the pendulum began to swing back
as the difficulties in collecting loan repayments increased, the strain in financial balances tightened
and assistance and support from the regulators were requested. The level of the financial and operat-
ing income was maintained primarily because of the high interest rates on the loans, but the structure
of their distribution shifted substantially. Administrative costs and depreciation were nearly frozen up,
and impairment and provisions grew at the expense of profit. This work shows that macroeconomic
policies allowed the expansion of the lending boom and encouraged its irrational development. Poor
operation and poor quality of the institutions not only allowed but also enabled direction of invest-
ments to financing of inefficient production structures. Underestimating the negative consequences
shoring up a dysfunctional institutional environment is deemed a form of irrationality; however, not
one of the immediate economic players acted to override the economic and political environment.
The financial and economic crisis currently affecting the country has its roots in the deficiencies of the
domestic macroeconomic policies, and therefore, the efforts toward overcoming these failures should
be directed at improved domestic macroeconomic management.

KEY WORDS: commercial banking; central banking; financial crisis

\section{JEL Classification: E52; E58; E65}

${ }^{1}$ Bulgarian Academy of Sciences, Bulgaria

\section{Introduction}

Until the introduction of the Currency Board Arrangement, that took place in 1997, the banking system in Bulgaria had been gradually decapitalized (Figure 1), and the hyperinflationary processes in the early second half of the 90s had an especially dramatic impact on the assets of the commercial banks (CBs). Due to the hyperinflationary wave, the depreciation of money ag-

Correspondence concerning this article should be addressed to: Garabed Minassian, Bulgarian Academy of Sciences 3 Aksacov Street, Sofia 1040, Bulgaria, e-mail: minasian@mail.techno-link.com gregates, had wiped out the country's ability to finance its own economic development. A telling example is the repeated contraction of the CBs' assets, - in terms of USD estimates; in 1993, the CB assets were evaluated at USD 24.8 billion, whereas four years later, they stood at USD 4 billion.

After the adoption of the CBA, a process of long and painful recovery and capitalization of the banking system began.

The objective of this article is to determine the following: (1) how the banking system and banking intermediation in the country developed over the last 


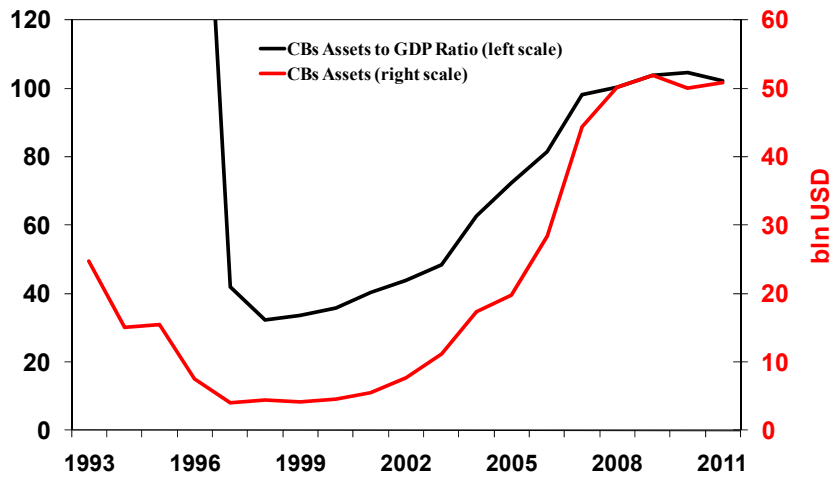

Figure 1. Bulgaria: Bank Intermediation



Figure 2. Commercial Banks and Non-resident Sector



Figure 3. Commercial Banks: Net Profit and Taxes 


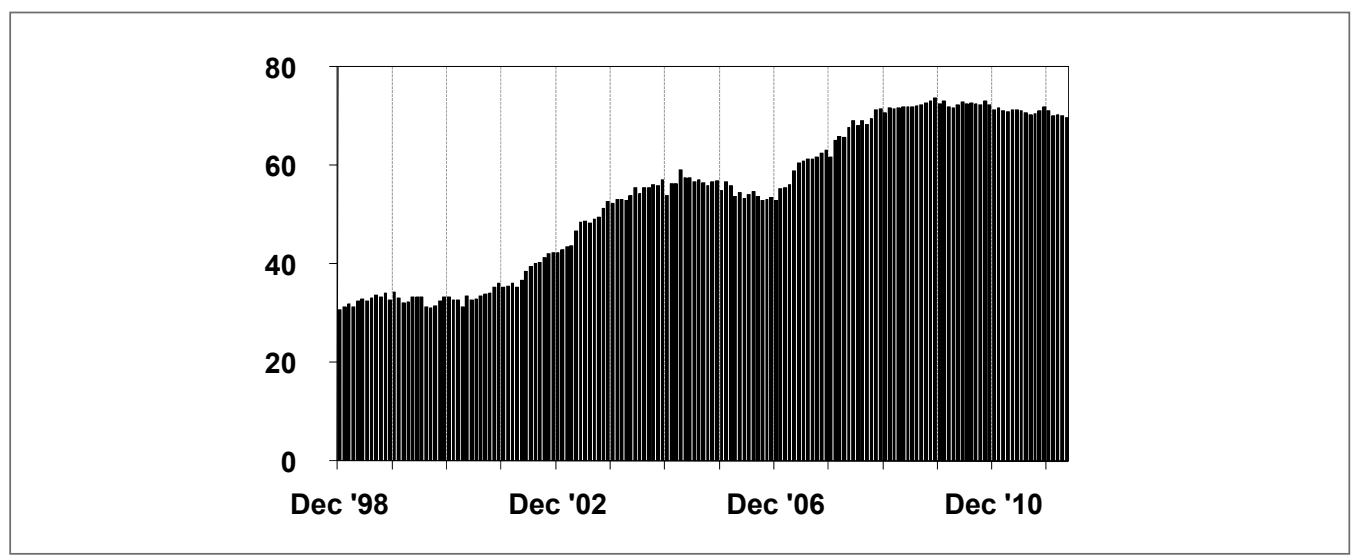

Figure 4. Claims on Non-financial Corporations, Households and NPISHs

ten years or so; (2) the reasons for and factors involved in the witnessed development; (3) the regulatory measures and assessment of their efficiency, and (4) the possibilityof financial and banking sustainability given that economic activities have remained unsteady.

As a rule, determination of the facts, arguments and estimates occurs in parallel. The data used in this investigation were publicly available from the official sources of macroeconomic institutions such as the Bulgarian National Bank (BNB) and the Ministry of Finance, although not all of their policies at the macroeconomic level may have been made public officially. The methodology applied is based on logic and the principles of market relationships in attempting to assess, characterize and combine all possible regulatory influences. The goal was to work out all possible and necessary assessments in parallel with their influences, which were considered both as independent management policies with their effects and as a complex scheme. A number of econometric dependencies revealed unsatisfactory estimates from the point of view of economic logic, and these were not addressed in this work. The current article does not analyze the reasons for the unsatisfactory econometric estimates, especially under consideration of banking interactions, which were discussed by other authors (Kazi \& Leonard, 2011). Instead, the emphasis is placed on establishing the interactions (in principle) of the relationship management in terms of outcomes and explanations. The analysis is aimed at assessing the financial and banking sustainability in the context of the overall economic environment.
The article is organized as follows: The major elements of the commercial banking policies are analyzed in the first five parts, together with reflection on the regulatory measures applied. The next part contains an attempt at systematizing the policy lessons, and the final part presents the conclusions and synthesis.

\section{Resource provision and lending policies}

Immediately following the 1996-1997, years of crisis, the CBs were exceptionally careful and restrained in formulating their lending policies. Confidence between lenders and debtors was at a notably low level. Because the CBs were reluctant to lend, their financial resources were not used to the fullest. During this period, the CBs preferred to export their resources and retain them as deposits with first-class foreign CBs (Figure 2). Therefore, only a quarter of the CBs' assets were realized as loans (Figure 4). Lending grew over time, however, and by 2005, it accounted for approxmately $60 \%$ of assets. Koetter \& Wedow (2010) proved that under the given circumstances, expanding the amount of bank credit has no significant effect on growth and that the quality of banking is more important. During the same year, the BNB undertook selected regulatory measures to cool the rate of lending: regulations were aimed at the operation of thecommercial banks' reserves held with the BNB. The lending market reacted positively to the regulatory measures, and the share of the loans in the CBs' assets fell gradually to near 52\%. This share was close to the average for the EU member 
countries and was estimated as relatively stable; the CBs' loan portfolio was diversified sufficiently against the credit risk (BNB, 2005).

Privatization of the CBs was completed in the early $21^{\text {st }}$ century. The new owners of the resident Bulgarian CBs envisioned positive prospects for development of the Bulgarian lending market and therefore, increased their activity. The results, in terms of the CBs' net profit, were impressive (Figure 3 ); the average growth rate of the CBs' net profit for the 2002-2008 period amounted to $31.6 \%$, given an average annual rate of growth in the GDP of $6.1 \%$ ! The gradual reduction in corporate tax, from 35\% (2000) to $10 \%$ (2008), made a significant contribution to this intensive dynamics as well. The flat rate in Bulgaria has remained at the lowest level in the $\mathrm{EU}$, but the future harmonization of the tax system within the EC is considered unavoidable (Wołowiec \& Soboń, 2011). The growth in the CBs' net profit provided a foundation and accounted for the unbalanced drive towards making the most of the opportunities for increasing lending.

The foreign owners of the resident CBs supported this lending. The deposits of non-residents, held with the resident CBs, rose gradually (Figure 2). These deposits represented foreign financial resources (most likely that of the owners) provided to the resident CBs to raise their potential for intensified lending. With the country's accession to the EU, this process became particularly active. The process of foreign capital penetration in the newly accessed member-countries of the EU is a typical feature of the period under consideration and has been noted in specialist literature (Krugman, 2008; Wilczyński, 2011). The highest inflow of foreign deposits into the resident CBs was reached in November 2008 (greater than 27\% of GDP), after which the trend broke. By 2011, Bulgaria occupied a position somewhere in the middle among the Eastern European countries in terms of financing the resident $\mathrm{CBs}$ via foreign $\mathrm{CBs}$, as observed by BIS-Basle (International Monetary Fund [IMF], 2012). As a matter of fact, these financial resources fed the overheating economy and were unsterilized (or only partly so). For 2007-2008, the overall growth of deposits in the banking system was estimated at approximately BGN 20 billion, and $60 \%$ of this total represented growth in the deposits of non-residents.
By 2008, the share of the loans to non-financial corporations, households and non-profit institutions serving households (NPISHs) in the CBs' assets had exceeded $70 \%$ and continued torise. The BNB estimated that the share of the "Loans and Advances" indicator in the CBs' assets in 2009-2011 accounted for over 80\% (BNB, 2011). Such an uncalculated and unwise emphasis on lending provided by the CBs no doubt incurred risks warranted great attention. The diversification of the CBs' portfolio with a view toward mastering the credit risk receded in the background in the face of the possibility for profit accumulation. The lending race was in full swing.

After 2008, the problem that the resident CBs faced was one of how to contain the pressure for impairment of the loans that had been issued. The CBs' assets continued to rise significantly due to inertia rather than as the outcome of an awareness of a positive return. At this point, the growth of deposits in the banking sector (such growth actually occurred; for 2009-2011, deposits with the CBs grew by nearly BGN 6 billion, given that non-residents' deposits fell by BGN 5.7 billion) was enabled by the higher level of domestic savings. Consequently, a process of gradual contraction of lending activities began. The non-resident depositors began to withdraw, which might be attributed to the feeling of insecurity in domestic macroeconomic management rather than international conjuncture. The corporate tax in Bulgaria is the lowest in the EU, and investors are charged higher tax rates in any other European country. Nevertheless, investments grew gradually, but the growth rate continued to shrink. This development was assisted by the resident CBs as well, which began to export financial resources more actively to retain them with the foreign CBs.

Foreign capital is particularly sensitive to the elements of domestic macroeconomic management. An additional funding risk arose from the origin of this capital, especially from difficulties in the banking systems of the home countries. This was the situation in Bulgaria, especially due to the predominance of the Greek banking capital. The inflow of foreign capitalvia deposits should be evaluated with close attention and controlled with the construction of respective buffers. A lack of possibilities for sterilizing the money supply due to the CBA in operation should raise an alert by the regulatory authority, which did not prove sufficiently alert under the conditions of Bulgaria. 


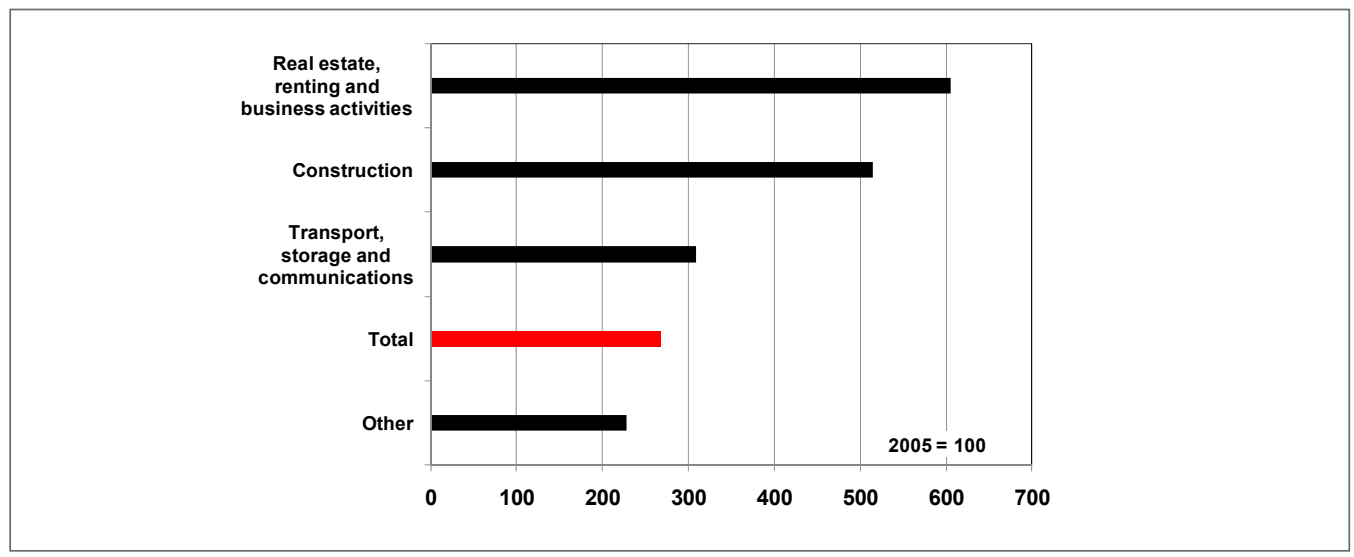

Figure 5. Lending Rate of Growth (2005-2008)

The credit risk linked with the sectoral structure of credits remained unappreciated as well. Granting credits to sectors such as „Real estate, renting and business activities”, and "Construction" and "Transport, storage and communications" became more prevalent (Figure 5). However, lending to the production sector lagged behind. The sectors of "Manufacturing”, „Mining and quarrying”, „Electricity, gas and water supply”, and „Agriculture, hunting, forestry and fishing" barely accounted for $16.5 \%$ of the overall credits in 2008 (4.7 percentage points less compared with 2005), and $37.4 \%$ were directed to „Households and NPISHs”. The major portion of the credits went to construction and the service sector $(46.1 \%$ in 2008, 5.7 percentage points greater than three years ago). Such a sectoral lending structure was typical of the EU and not only of the EU. In fact, the mania for investing in real estate, renting and business activities seemed universal (DG Enterprise and Industry, 2012; European Commission, 2011). The prevailing public opinion was that real estate prices would never collapse (Roubini \& Mihm, 2010). This sector composition of credits cannot be deemed sustainable or promising for the future.

The development described was the outcome of the euphoria for profit that caused the banking circles to become carried away. Prices for real estate shot up with positive expectations, the flow of foreign financial resources continued and the lending race proceeded in full swing. In retrospect, sobering and slow-down should not have taken long to arrive.
Regulation of the lending sector composition lies outside the authority of the BNB. This type of activity requires and presumes a much better coordination between the BNB and the government. It is a public secret that real estate transactions during this period were officially effected at artificially low prices (roughly ten times lower than the real price paid), which encouraged profiteering in real estate. Control of licenses for new construction was a formality that enabled accelerated investment on a large scale, and construction sites were quickly designed without care for the future, using easy money. All these activities became possible because the various institutions functioned poorly.

In parallel with this process, the formal grounds for charges of illegal (criminal) deeds were eliminated because the huge amount of real estate acquired was officially accounted at unnaturally low prices. For experienced defenders of the law, it is not difficult to find a seemingly satisfactory explanation of how large buildings were acquired at artificially lower official prices and thus escape legal prosecution.

The government is the authority that should install order in this type of speculation. If the government had not allowed cheating in the sales and trading prices of real estate, then the incentives for profiteering in this field would have been eliminated.

\section{Sobering}

Roubini \& Mihm (2010) found that banking security is transient and erratic. After 2008, the banking pen- 




Figure 6. CBs Equity Growth Composition



Figure 7. Commercial Banks and Non-resident Sector

dulum swung back towards center. Difficulties were more frequently encountered in collecting the credits granted, the tension in financial balances increased and aid and support were solicited from the regulatory authorities. Lending activities gradually died down, and nominal annual average rate of growth in lending approached $2 \%$ while the real rate was almost zero.

The significantly deteriorated financial results of the commercial banking industry are illustrated by the dynamics of return on equity (coefficient ROE, Figure 3). Until 2008, the ROE remained at a relatively steady level of over $20 \%$, but in the following years, it fell sharply. The coefficient dynamics reflects the depth of the financial crisis of the CBs. The race for dominance in the credit market over the previous years, which was insufficiently sanctioned by the BNB, had turned the economic picture upside down and, theoretically, it should have been expected.

The events at the end of 2008 had an influence on concern in the BNB sector over the soundness of the commercial banks, as reflected in the growth of the $\mathrm{CB}$ equity (Figure 6). Immediately after in the following year, the total CB equity grew by almost a fifth (given an asset growth of $1.9 \%$ ), allocated primarily to ,...the 





Figure 8. Liquidity Coefficients by Maturity Time Bands and Groups of Banks December 2011

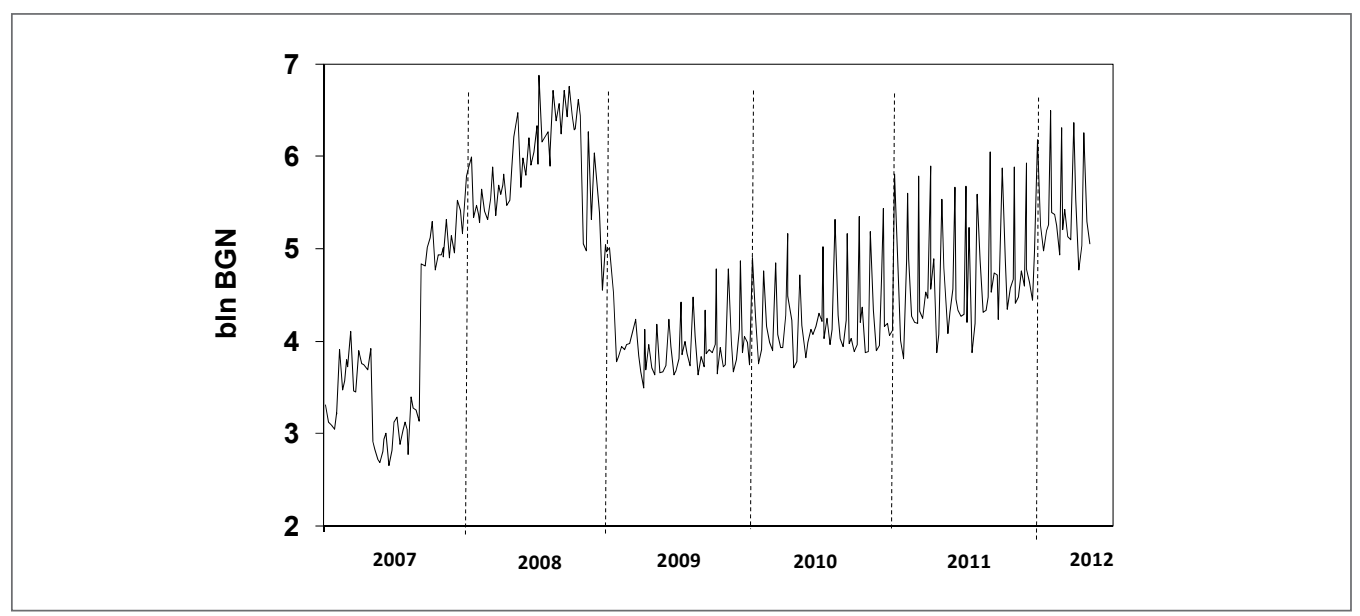

Figure 9. CBs Reserves with the BNB

Until the beginning of 2009, the weekly fluctuations observed might be considered normal. Later, however, a certain regularity of fluctuations with expanding amplitude was outlined. By the end of each month, the CBs deposited the funds needed to ensure that the required aggregate monthly size of MRR was available, and this moment corresponds to the peaks observed in Figure 9. Immediately afterwards, the CBs would withdraw up to a fourth ormore from the MRR. By 2012, this amplitude had clearly shrunk but has remained quite large.

A logical explanation for the process observed is that the CBs need liquidity, and thus they resort to using their own reserves maintained with the BNB.

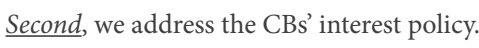

An indirect indicator for the liquidity problems experienced by the CBs is the dynamics of interest rates on time deposits (Figure 10).

A steady growth was observed in the interest rates on deposits of an agreed maturity (time deposits) throughout 2008. The average annual inflation rate (CPI) for 2008 was $12.3 \%$ (Table 1) and could account for the rise in interest rates, but during the following year, the picture became somewhat different. In 2009, the CBs were ready to offer a real interest rate on deposits of agreed maturity of over $4 \%$. For the same year, the average yield-to-maturity of the global bonds in 


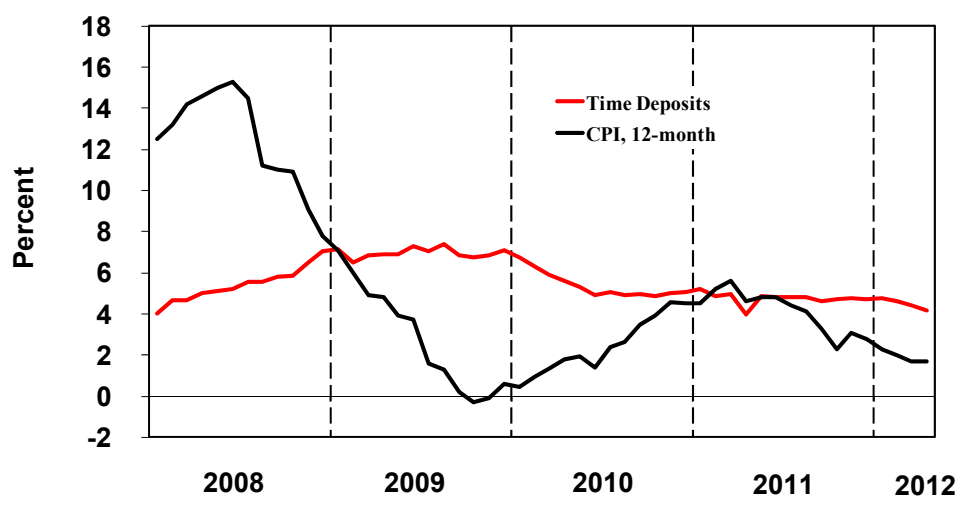

Figure 10. Interest Rates on Time Deposits and Inflation (CPI, 12-month)

Table 1. Comparative Return (average annual data)* (percent)

\section{Interest on Deposits with} Agreed Maturity (new business)

\section{8}

2009

2010

2011
5.2

BGN Inflation (CPI)

5.4

7.0

6.8
12.3

2.8

2.4

4.2
Yield to maturity of the 10-year global LTGS in EUR

6.1

5.8

3.6

3.3

Notes:

* The information is from 2008, because data from the previous years are methodologically inconsistent.

EUR, issued by Bulgaria (issue 2002 and maturity in 2013) was $5.8 \%$, i.e., it was more profitable for investors to maintain deposits with the Bulgarian resident CBs for a guaranteed income without risk than to invest in risky global bonds.

A similar situation occurred in the following two years. In the first half of 2011, the real interest rates on time deposits became zero, but the process of recovery of the real interest rates was subsequently renewed.

The CBs have their own reasons for incurring such costs, and the explanation can only lie in the lack of sufficient liquidity. The CBs pay a high price to attract new deposits and compete amongst each other because they need fresh financial resources. At the same time, interest rates on the interbank money market fell to symbolic levels (e.g., an annual rate of approximately0.2\%), but what was provided consisted of almost exclusively overnight deposits. The CBs demonstrated a need for long-term liquidity. Deposits up to BGN 100 thousand are officially guaranteed and thus there were no demands waiting for the withdrawal of financial resources, i.e., there was no fear of loss in the case of probable insolvency and a need for overnight liquidity.

Third, we examine the composition of the CBs' assets.

In Figure 4, we can trace the change in the share of the CBs' loans via their assets (the data are given for the entire banking system). This information was presented in the official analytical materials of the BNB (BNB, 2012). By the end of 2011, the CBs' loans and advances constituted almost four-fifths (78.6\%) of the CBs' as- 
Table 2. Government Security Auctions (million BGN)

\begin{tabular}{lccc}
\hline & Nominal Value of the Offer & $\begin{array}{c}\text { Nominal Value of the Bids } \\
\text { Approved }\end{array}$ & Bid-to-cover Ratio \\
\hline $\mathbf{2 0 0 8}$ & 340 & 874 & 2.6 \\
$\mathbf{2 0 0 9}$ & 545 & 1097 & 3.3 \\
$\mathbf{2 0 1 0}$ & 948 & 3136 & 2.3 \\
\hline
\end{tabular}

sets: a tenth (9.9\%) represented money and money balances with the central bank, the investment portfolio accounted for less than a tenth $(8.2 \%)$ of the assets and the remainder $(3.3 \%)$ included other assets. Given this composition of assets, it is far-fetched to claim that sufficient liquidity existed. The CBs' resources were fully engaged. Sufficient (plentiful) liquidity was available in the beginning of the century when the CBs' loans accounted for nearly a quarter of the assets.

If CBs had maintained sufficient liquidity (primarily through containing of lending), then the reasons obviously could be found in the predection of difficulties in collecting the established loans, either in the present or in the future, and not in the judgment of a lack of current projects worth crediting. This conclusion forces us to look back to the years in which lending remained out of control.

"We should look for the prerequisites for growth rather than the prerequisites for crisis" is a statement made by Mises (2006). The consequences from resorting to regulation (or the lack of regulation), if the situation were not properly assessed in time, would reflect by undesirable developments.

Fourth, we illustrate the sharp deterioration in the final financial results of CBs.

When evaluating the lending policies of CBs after 2008, we should keep in mind the sharp deterioration of their final financial results (Figure 3 ) as well as the natural and logical search for and use of all possible means and instruments for a positive upturn. In 2011, the CBs committed almost a third more equity than in 2008, whereas the net profit for the same period was $58 \%$ lower. Shareholders would not have tolerated a management that showed timidity, insecurity and passivity in managing the CBs, and even more so with sufficient liquidity available. The excuse of "no projects of good quality available" would simply not hold true under a market environment in which equilibrium is always achieved in striving for optimization from both sides and a full commitment of all resources available.

The abovementioned considerations and arguments show that the CBs continued to experience certain liquidity difficulties, which were eventually reflected in their credit passivity, and respectively in the shrinking of investments in the economy.

The problem with liquidity in economics has certain ambiguous dimensions.

Table 2 shows the aggregate results of GS auctions that took place in the recent years. Interest was quite high in these auctions and rose even after 2008. Until 2008, these events included the government budget which realized surpluses and did not need to attract additional financial resources, and therefore the quantities of Government Securities (GS) offered on the money market were minimal. The situation changed after 2008, when the demand for financial resources on behalf of the Ministry of Finance rose significantly and the demand for GS from local investors rose even faster. The high values of the cover coefficients of the issues implied a high liquidity available in the country (not with the CBs), which was ripe for realization.

In the primary GS market for the period under consideration, the non-banking institutions, i.e. insurance companies, pension funds, non-banking financial in- 
Table 3. Holders of Government Securities (percent)

\section{Banks}

2010

2011
Others*

41.1

44.4

Notes:

* Insurance companies, pension funds, non-banking financial institutions, companies, individuals;

Table 4. Financial Account of the Balance of Payments (million EUR)

\begin{tabular}{lccc}
\hline$Y_{r}$ & Assets & Liabilities & Total \\
\hline $\mathbf{2 0 0 8}$ & -670 & 12177 & 11463 \\
$\mathbf{2 0 0 9}$ & $-\mathbf{1 1 8 7}$ & 2369 & 1163 \\
$\mathbf{2 0 1 0}$ & $\mathbf{- 7 8 3}$ & & -699 \\
$\mathbf{2 0 1 1}$ & $\mathbf{- 9 7 1}$ & 109 & -1194 \\
\hline
\end{tabular}

stitutions, companies and individuals, became much more active (Table 3 ). For the sake of thoroughness, we should add foreign investors as holders as well, but their participation was limited to one percent of the overall quantity of GS issued on the internal money market). These products were legal entities that accumulated free financial resources and were searching for opportunities for investment with a view towards rational management of the money funds and provision for a return. The preferences included to investing in GS because these products enjoyed higher security and a much longer maturity, which was of considerable importance as well. The one-year GS, issued in 2010, accounted for a tenth of the overall issue of GS, and more than half had a 10-year maturity. At the same time, the predominant promotion of CBs was for de- posits of 3-6 month maturity, which obviously differed from what investors sought.

In addition, the cross-border flow of financial resources from residents included in the financial account of the balance of payments (Table 4) was also predominantly sourced from non-banking investors.

The information quoted implies that the various institutional funds in the country enjoyed liquidity that remained underused. Simultaneously, the CBs showed signs of liquidity difficulties. The two sides did not meet, mostly due to structural imbalances. Institutional investors were interested in long-term lucrative investments, whereas the CBs would have rather attracted short-term funds with the expectation of lowering their interest rates costs and receiving improved return on the loans made. 
Table 5. Currency Composition of the Funds Attracted by CBs (percent)

\begin{tabular}{llll}
\hline Yr & BGN & EUR & Other \\
\hline 2007 & 41.2 & 51.9 & 6.9 \\
$\mathbf{2 0 0 8}$ & 39.8 & 53.9 & 6.3 \\
$\mathbf{2 0 0 9}$ & 35.4 & 58.7 & 5.8 \\
$\mathbf{2 0 1 0}$ & 41.3 & 5.7 & 6.7 \\
$\mathbf{2 0 1 1}$ & 45.2 & 52.0 & 6.8 \\
\hline
\end{tabular}

Table 6. Currency Composition of the Loans (percent)

\begin{tabular}{llll}
\hline Yr & BGN & EUR & Other \\
\hline 2007 & 43.7 & 51.5 & 4.8 \\
$\mathbf{2 0 0 8}$ & 40.0 & 56.1 & 3.9 \\
$\mathbf{2 0 0 9}$ & 38.5 & 57.9 & 3.6 \\
$\mathbf{2 0 1 0}$ & 38.0 & & 3.8 \\
$\mathbf{2 0 1 1}$ & 33.9 & 58.3 & 4.8 \\
\hline
\end{tabular}

\section{Currency hedging}

The CBs adopt a certain strategy in determining the foreign exchange composition of their own assets and liabilities as a type of anti-crisis safety measure. The CBs management is able to manage the currency composition of its assets and liabilities in accordance with its own estimates, expectations and preferences. The management of currency composition is carried out by pursuing a specific interest rate policy for each individual currency component.

Table 5 illustrates the currency composition of the funds attracted by the CBs (by the end of the year), and Table 6 displays the currency composition of the loans granted from the resident CBs in the country. (In Table 6, the sum by years is less than $100 \%$ because there is one additional component that is not presented, namely „Impairment”).

Table 5 shows that a shift in the CBs' behavior was recorded in 2009 with respect to the currency composition of the financial resources attracted. Until 2009, the share of the BGN- attracted resources progressively diminished at the expense of the EUR-attracted resources. Over the following two years, however, a sharp change occurred, and the CBs began to look more intensely for liabilities in BGN, also expressed by the higher interest on time deposits offered in BGN.

The changes in the currency composition of the loans followed a strict logic of contraction of the BGLloan share at the expense of the EUR-loan share. 




Figure 11. CBs Administration Costs (12-months)

This change coincided with fading hopes for a quick accession to the Euro area.

There are no chance phenomena with bankers; as a rule, their behaviors are well-thought out and calculated. Therefore, the question that remains is why did the model of banking behavior change?

The party that gains under a substantial depreciation (devaluation, crisis) of the local currency is the borrower, and the party that loses is the lender. If the local currency (the Bulgarian lev) crashed, the bankers who had granted BGL-loans would have lost. As a consequence, the depositors that maintained BGN deposits would have also lost.

The process described is highly inertial (structural statistics are determined by balances, not by new business), and thus inconsistent fluctuations are unlikely. The CBs would rather offer higher interest on deposits in BGN (compared with deposits in EUR), i.e., charge themselves with higher current interest costs because they suspect a possibility for collapse of the Bulgarian lev in future. By analogy, they would rather grant additional EUR-loans at lower interest rates because they have greater faith in the stability of the EUR. Managing the currency positions of the CBs contributes to hedging the currency risk in accordance with the prevailing expectations.

Regardless of the strains and debt perturbations present in the Euro area, the participation of other currencies (in additions to the $\mathrm{BGN}$ and EUR) in the $\mathrm{CB}$ structures of assets and liabilities is relatively minimal and steady. Bankers do not foresee serious changes in the European currency configuration.

The behavioral model of bankers represents a peculiar vote on and assessment of the nature of macroeconomic management and is a form by which the domestic (hidden) bankers provide a credit rating for a specific macroeconomic policy. It seems that bankers were not inclined to voting much confidence in the present macroeconomic management.

\section{Income and Expenses Composition}

The crisis of 2008 revealed many problems connected with the assessment and adoption of various types of risks in commercial banking. One of these problems is the way in which the remuneration of employees in the banking sector was worked out (Attali, 2008). It is logical for remunerations to follow the dynamics of the final financial results from the banking operations, but global experience has shown that this is not always so, especially with CBs of dubious success.

Figure 11 shows the development of the CBs' administration costs in Bulgaria for the period 20042012. The elements of the CBs' income statement encompass two elements: (1) Staff expenses and (2) General and administrative expenses. The structure of the indicator is relatively steady over time with small variations, e.g., two-fifths (or slightly more) of the administration costs account for staff expenses and the general and administrative expenses make up the rest. 


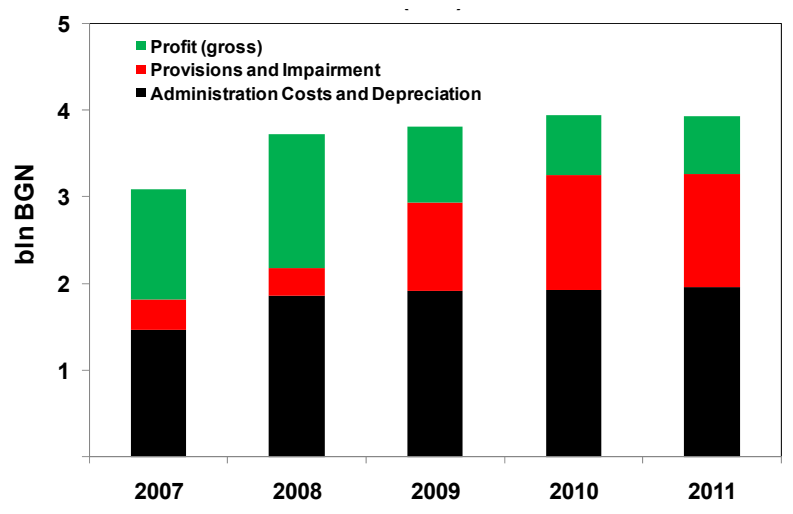

Figure 12. Distribution of Financial \& Operating Income (net)

The trend of the indicators until 2008 seems quite sharp. For correct evaluation, this trendshould be juxtaposed with an analogical trend, e.g., the rise in labor pay in the country. The National Statistical Institute recorded that the average annual salary of those employed on labor contracts in the country for 2003 was BGN 3280. This number grew to BGN 6538 in 2008, i.e., when the average annual rate of growth for the period was $14.8 \%$. At the same time, for the same period, the average annual rate of growth in administrative costs of CBs was $18.2 \%$.

The gross pay of bankers' labor outstripped the average labor pay in the country but not by much, i.e., there are no grounds to claim that bankers abused the possibility of raising their income. The level of pay in the country was rather low compared with European standards, and it is therefore natural to record relatively higher rates of growth under these circumstances.

The internal structure of pay by individual labor categories in the banking system is no doubt essential, but this information remains confidential. The narrow circle of top management of the CBs enjoyed an income several times higher than that of the average employee, but this is the usual practice.

After uncovering situations of misuse of bonuses paid out to the managerial elite of certain CBs in the world, the regulator $\mathrm{BNB}$ reacted. For the first time in its operation, the BNB adopted a special Ordinance No. 4 (of $21^{\text {st }}$ of December 2010, available on the Inter- net) on the requirements for remunerations in banks. Ordinance No. 4 is a type of guarantee that no such misappropriation of the attracted funds by the CBs will be allowed.

The rise in the CBs' administration costs after 2008 was suppressed (Figure 11). This process occurred in harmony with the poor financial indicators of the CBs. The average annual rate of growth in the average annual pay of those employed on labor contracts in the country in 2011 relative to that in 2008 was $8.6 \%$, whereas for the same period, the CBs' administration costs rose (at an average annual basis) ten times more slowly, namely, a rate of $0.8 \%$. In accordance with the official statistics, the average annual pay in the „Financial and Insurance Activities" sector exceeded the average for the country by 2.23 times in 2008, and two years later by 2.08 times. Banking management showed prudence in determining the remuneration of those employed in the CBs, which in a different context implied poor expectations for the development of the business in the short run.

Figure 12 is indicative of the core problems experienced by the CBs. Until 2008, financial and operating income (net) had steadily increased. This increase resulted from the lending activities, which were considered to be exceptionally lucrative and prospective. Real estate prices rose out of control, loans were repaid and everything seemed to support the positive expectations of the moment. As always, a sobering trend oc- 


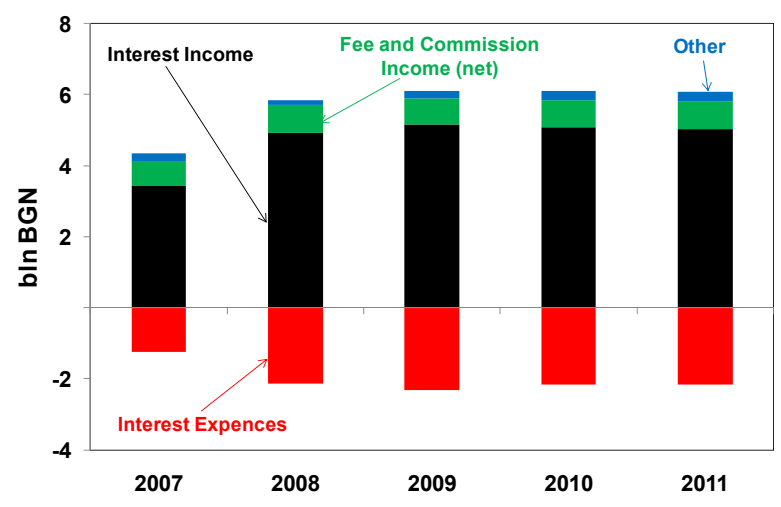

Figure 13. Composition of Financial and Operating Income

curred suddenly. The level of financial and operating income (net) over the following years was retained primarily due to the high and floating interest rates on the loans, but the structure of their distribution changed substantially. According to the three main elements in Figure 12, administration costs and impairment almost froze up completely, but the other two were merged. Impairment and the ensuing provisions grew due to the irrecoverability of the loans and ate up increasingly more of the remaining profit.

After four years the normalization sought in the income statement structures of the banking system had drifted substantiually. The structure of Figure 12 would have been much more unfavorable for the CBs, if the old criteria for classification of risk exposure in the individual risk groups of „watch exposures”, „nonperforming exposures" and "loss" had been maintained (had they not been extended to twice as long in time instead). A hidden revolving door of bad debts was observed (which statistics are unable to capture) in the hope that borrowers would manage to recover their business profitability in time. The CBs did not demonstrate a desire to begin cashing the collateral pledged. Obviously, there were no acceptable conditions for that outcome.

For the overbuilt areas that consumed a notably large amount of credit resources, the process runs slowly and sluggishly: investors are not prone to lower prices, and their expectations match the traditional beliefs that the market will not only pick up again but that it must pick up. The process extends in time together with the normalization of lending. Certain institutional changes have now restrained the speculation in real estate, and moreover, the real estate market appears saturated at the moment. The other type of business that acts as a debtor to the CBs (and lies in the service sector primarily) suffers from the present crisis in consumer psychology. The latter can be stated somewhat in terms of "better be prepared for a poor tomorrow than to loosen one's purse hoping for higher income in the future".

Developments in the structure of the financial and operating income were also frozen (Figure 13). After 2008, the CBs tried to maintain the level of interest income attained primarily through operation with the agreed floating interest rates on credits. An analogical effort to maintain the level of interest expenses was observed; in 2009, increased efforts were launched to attract deposits (Figure 10), but the effort put towards maintaining them outweighed them, however.

Contradictory opinions exist with thespect to the CBs' fee and commission income. According to the data, their size is also relatively stable, remaining within a fifth of the financial and operating income. An entirely different matter is that, given the situation, the fees and commissions have provided for the CBs' profit (Figure 14), and they have become vital for the operation of the banking system. 


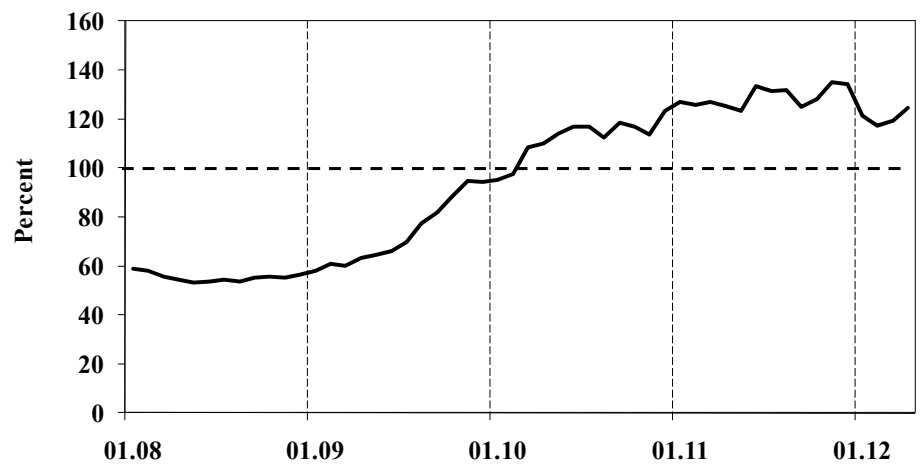

Figure 14. Fee and Commissions Income (net) to CBs Profit Ratio (yearly)

Competition in the banking sector is functional as a whole and will not allow for an uncalculated transfer of CB difficulties to borrowers. Under the CBA, there are no mechanisms for directly influencing the CBs' interest rate strategy and the creation of unilaterally beneficial conditions in the lending process. What is missing, however, is an adequate institutional structure for contractual relationships between lenders and borrowers that might allow a certain level of arbitrariness on behalf of the CBs in changing the interest rates on contracts already signed. In Bulgaria, Hristov (2012) has been a staunch champion of introducing an adequate institutional framework to fairly settle the relationships between lenders and borrowers.

\section{Policy lessons}

There is an opinion in certain professional economic circles that the financial and economic crisis of 2007-2008 arose because of excessive faith in the rationality of the market and that of the participants in the markets (Attali, 2008; Stiglitz, 2010b). Regulations shrank steadily to allow for the free operation of market initiative and this initiative managed to create and spin a broad web of speculative threads, which were wound round and sucked out the economic forces - in the interest of the "irrational" market masters. These actions had their own redistribution effects, which went beyond the direct financial and economic operations.
The main lesson should be aimed in the direction of making clear the type, nature and extent of necessary and adequate regulation.

Regulation is achieved through:

(1) Macroeconomic policies (monetary and fiscal);

(2) Build up of well functioning institutions.

What occurred in the latest crisis confirms the opinion that the banking system cannot be examined in isolation from the overall macroeconomic environment, i.e., by itself. The successful and adequate regulation of the banking system exceeds the capacity of the central bank and is a function of the management of the financial and economic interaction at a national level. The coordinated and joint management of macroeconomic policies by the three institutions (the National Assembly, government and the central bank) is of crucial importance for maintaining steady economic progress, which in turn is a major prerequisite for keeping the financial system sustainable. Managing processes by primarily taking into consideration the narrow establishment interests (e.g., the Ministry of Finance) might provide a partial success in a given field but can create failures in other accompanying fields. At first sight, fiscal policy and imposition of sector priorities at a national level affect the redistribution process, but experience has shown that they can lead in parallel to restructuring of the financial resources with a direct impact on the 
sustainability of the banking system, quite often with consequences that can be difficult to foresee.

Just prior to Bulgaria's accession to the EU and during the first years of its membership, the inflow of foreign capital in the country recorded a considerable increase. The country adjusted exceedingly quickly to this capital meat-dish, and it appeared as if the horn of plenty would never be exhausted. Sobering trends, together with sharp contraction of the financial inflows have had a painful impact on financial and economic development. It is true that the financial crisis reflected most rapidly and significantly on the cross-border movement of capital, but it is also true that money does not shy away from an opportunity described by foresight, transparency, safety and profit.

It is indicative that according to Transparency International, Bulgaria has firmly held the position of the most corrupt country in the EU, and moreover, this situation has continued to worsen (Minassian, 2011). At its essence, corruption is a political not an economic problem, i.e., it exists because the political class cannot (or does not want to) eradicate it. The black market has not been cornered and also has been steadily assessed at a third or more of GDP. Shortsightedness in managing these developments undermines the basis of rational economic activities and puts off investors. The unassessed and complex consequences are connected with the shakeup of the banking system.

Macroeconomic policies enabled the expansion of the credit boom and its irrational nature. However, if one has to label the situation of 2007-2008, then the latter would be best described as an institutional crisis. Stiglitz (2010a) is one of the economists who carried out a detailed analysis of the role of the institutions in the current financial and economic crisis.

The poorly performing institutions enabled and made possible the direct investment in the financing of inefficient production structures. Misjudging the negative consequences from a disorderly maintained institutional environment is a form of irrationality, not of the immediate economic agents but of the acting players managing the economic political environment.

The present government in Bulgaria is persistently pushing the idea that financial sustainability (understood as an effort to balance the government budget) is a requirement and that economic prosperity on the way to converging on the core of developed econo- mies in the EU is inevitable (automatic) in the future. Bareau proved that ,...the convergence of the developed and less developed countries is not automatic but ... requires an appropriate social and political infrastructure" (as cited in Gilpin, 2001).

The roots and grounds for such a policy must be sought in the principles followed by international financial organizations (mainly the IMF) for interaction with the individual countries. These policies are related to the material expression of the ideas of the so-called structural regulation formulated in the mid1980s by former Secretary of the Treasury of the USA G. Baker in connection with solving the debt problem on a global scale, and later (1989), with the recommended ten types of reforms for the developing countries advocated by Williamson. These ideas have finally become known as the Washington Consensus (WaC) (Gilpin, 2001).

History has presented its evaluation of the suggestions in the WaC, and it is by far unambiguous. Many analyses can be found in specialist literature of the application of WaC. Aparticular critic of this approach is Stiglitz (2003), who said that ,... the net effect of the policies set by Washington Consensus has all too often been to benefit the few at the expense of the poor, the well-off at the expense of the poor". In their most recent Bulgarian edition of 2009-2012, the recommendations were glorified as defending market fundamentalism or neo-liberalism, and their name was formally replaced by the Maastricht criteria (MC) for the country's accession to the Euro area. The treatment of both groups of principles ( $\mathrm{WaC}$ and $\mathrm{MC}$ ), however, has been one and the same: these poilicies must be paired with unconditional compliance as a guarantee for the respective countries' future social and economic prosperity.

A similar policy can be defined as a type of neoclassical caricature; Following it unflinchingly represents a demonstrative refusal to learn from the lessons of financial and economic history.

The $\mathrm{WaC}$, on the one hand and $\mathrm{MC}$, on the other are constructed with different initial conceptions and are aimed at formally different (and even incomparable) goals. What makes them comparable is the practice of treating them as absolute truths and pursuing them blindly. All secondary effects are ignored as well certain specific features for each given case, in the firm belief that there can only be positive consequences. 
Both with the $\mathrm{WaC}$ and the $\mathrm{MC}$, the positive effect of the policies recommended might take place given the obligatory assistance of adequately constructed and efficiently functioning public market institutions.

A major issue of theoretical and practical importance is if and how far pursuing a policy of so-called financial stability (in the form of a balanced government budget) is a real guarantee for attaining the final goal of the economy, i.e., steady rates of growth in the prosperity of the people. The most general (but not the only) measure of this final goal are the rates of GDP growth in combination with the accompanying indicators of all factors connected with overall human well-being.

Scientists have long worried about the problems of measuring and the measurements of economic prosperity. In the early 2008, the president of the Republic of France, N. Sarkozy, appointed a special commission in response to ,... increasing concerns about the adequacy of current measures of economic performance, in particular those based on GDP figures, and to broader concerns about the relevance of these figures as measures of societal well-being, as well as measures of economic, environmental and social sustainability" (Stiglitz, Sen, \& Fitoussi, 2010). The commission headed by Stiglitz involved other Nobel laureates in economics and outstanding representatives of social and economic thinking

"Too often we confuse ends with means"; this judgment was made in the report of the special commission appointed by the President of the Republic of France, N. Sarkozy. The final goals of the economy are most generally the indicators for well-being and good quality of life, not individual indicators that we prefer to use as measurements of so-called called financial stability. It is a delusion to speak of financial stability when there is no economic stability. Government expenditure is contracted, the deficit of the government budget is under control, the international foreign exchange of the country is at an acceptable level, but what does this mean? The reduction in government expenditure as an end in itself cripples public activities of long-term impact (e.g., education, healthcare etc.) and the unfavorable consequences will be felt dreadfully in the near future. For the sake of balancing the government budget, the government let itself delay the settlement of certain overdue large-scale obligations to sub-contractors of government orders, which in turn created prerequisites for a chain accumulation of inter- company obligations and caused tension at a macroeconomic level (Sariyski, 2008; Taseva, 2012).

Central bankers claim that the Bulgarian taxpayer has not spent money to save the Bulgarian CBs, but this is a surface observation. The highly restricted lending due to the excessively high interest rates is connected with the consistent and tangible shrinking of all investment activities in the country, which sounds ominous in the long run given the exceptional technological backwardness of the Bulgarian economy. In addition, the highly restricted lending forced economic players at the microeconomic level to activate commercial lending, which is a type of time bomb.

Additionally, it is not possible to speak of domestic financial sustainability when residents prefer to export their resources abroad.

What determines the health of an economy is the availability of economic sustainability, and the latter in turn determines social and economic prosperity. If there is no economic sustainability, everything else (including the so-called sustainability of government finances) is merely rhetorics.

\section{Conclusion}

The banking system is a component of the financial and economic institutional structure of society, which is of crucial importance for the normal development of economic processes. Formally, the responsibility for keeping the banking system sustainable lies with the central bank, but as a matter of fact, the banking system becomes the meeting point for almost all elements of macroeconomic management. An adequate assessment of the banking system situation and its regulation presumes taking a view that is higher than banking coordinates, from the position of the national (and the supranational) economy. The sustainability of the banking system is functionally linked to and correlates with the sustainability of economic development. Problems in the banking system might arise from inadequate regulatory measures undertaken by the central bank, but in a prevailing number of cases, they are the outcome of deficiencies in macroeconomic management as a whole. The soundness of the banking system is linked to the value of transaction costs in the economy.

The financial and economic crisis that Bulgaria has experienced is the outcome of the domestic macroeconomic management of poor quality. Havrylchyk \& 
Jurzyk (2011) found that direct evidence did not exist for the transfer of negative financial impacts from the parent bank to its subsidiary banks from Central and Eastern Europe, and Acharya \&-Schnabl (2010) came to the conclusion that reducing global imbalances was not a panacea for preventing banking crises under the conditions of inefficient regulation. Investment banking was not developed in Bulgaria, and it cannot be blamed for the crisis. Even the shrinking external demand cannot be named as an exogenous reason for the difficulties that the country has experienced. In 2011, for example, the export of goods and services exceeded its pre-crisis level of 2008 by a quarter, whereas the imports of goods and services were almost a tenth lower, i.e., there are grounds to claim that in the critical situation, Bulgaria caused difficulties for its trade partners rather than the opposite.

However, the globalization of developments, and of economic thinking most of all, reflects on the way in which domestic economic processes take place, and their manifestations follow the usual process of „contamination" (Baur, 2012; Ismailescu \& Kazemi, 2011; Wilczyński, 2011). It is a fact that the sharp withdrawal of foreign capital from Bulgaria coincided with the global recession and had a significant impact on the shrinking of national output, but such a reflection of financial and economic perturbations has occurred all over the world. If we trace the quotations of the Bulgarian Brady bonds of the 90 s in the last century as a barometer of investment interest towards the country, it becomes clear that they were influenced by global conjuncture, although Bulgaria did not participate in this specific process of crisis. A fall in investment interest in Bulgaria was witnessed during the Mexican debt crisis of 1994 (tequila effect), after the financial crisis in South-east Asia in 1997 and also (especially so) during the Russian financial crisis a year later. The effect of "contamination" in terms of the ebb in investment interest was impulsive, but the length of the recovery of the pre-crisis levels correlated positively with the efficiency of macroeconomic policy.

Financial and banking sustainability is an element of overall economic sustainability, which results primarily from endogenous management policies. Economic history has persistently confirmed that in the end "nothing is really exogenous" (Ray, 2004). The explanation of the financial and economic processes observed and the search for sustainability cannot take place except within the context of an integrated theory of finance and macroeconomics (Mehrling, 2004).

\section{References}

Acharya, V., \& Schnabl, P. (2010). Do Global Banks Spread Global Imbalances? Asset-Backed Commercial Paper during the Financial Crisis of 200709. IMF Economic Review, 58 (1), 37-73.

Attali, J. (2009). Кризата, а след това? [The Crisis, and After That?] (M. Petrikova, Trans.). Sofia: RIVA

Bulgarian National Bank (2012). Banks in Bulgaria (October - December 2011). Retrieved from http:// www.bnb.bg/bnbweb/groups/public/documents/ bnb_publication/pub_b_in_b_2011_12_en.pdf

Bulgarian National Bank (2011). Banks in Bulgaria (July - September 2010). Retrieved from http:// www.bnb.bg/bnbweb/groups/public/documents/bnb_publication/pub_b_in_b_2010_09_ en.pdf

Bulgarian National Bank (2010). Annual Report 2009. Retrieved from http://www.bnb.bg/bnbweb/ groups/public/documents/bnb_publication/anual_report_2009_en.pdf

Bulgarian National Bank (2005). Commercial Banks in Bulgaria (October-December 2005). Retrieved from http://www.bnb.bg/bnbweb/groups/public/ documents/bnb_publication/c_bnb_p_banks_ in_b_200512_en.pdf

Baur, D. (2012). Financial Contagion and the Real Economy. Journal of Banking \& Finance, 36 (10), 2680-2692.

DG Enterprise and Industry. (2012). EU Industrial Structure 2011. Trends and Performance. Luxembourg: Publications Office of the European Union.

European Commision. (2011). European Competitiveness Report 2011, SEC(2011) 1188 final. Brussels, European Commission.

Gilpin, R. (2001). Глобална икономика. Разбиране на международния икономически ред [Global Political Economy. Understanding the International Economic Order] (L. Benatov, Trans.). Sofia: Damian Yakov.

Havrylchyk, O., \& Jurzyk, E. (2011). Profitability of foreign banks in Central and Eastern Europe: Does the entry mode matter? The Economics of Transition, 19 (3), 443-472. 
Hristov, L. (2012). Финансистьт Любомир Христов предложи 6 мерки за равенство на гражданите с банките [Granting credits is risky, the country is run poorly]. Retrieved December 2, 2012 from http://grajdani.org/?p=4775

International Monetary Fund (2012). World Economic Outlook. (April 2012). Growth Resuming, Dangers Remain. Retrieved from http:// www.imf.org/external/pubs/ft/weo/2012/01/ pdf/text.pdf

Ismailescu, I., \& Kazemi, H. (2011). Contagion or Interdependence in Emerging Debt Markets? The Banking and Finance Review, 3 (2), 1-15.

Kazi, M. H., \& Leonard, J. E. (2011). Impact of the global recession on the Southeastern European Banking Sector: A simple exposition. Journal of New Business Ideas \& Trends, 9 (1), 18-27.

Koetter, M., \& Wedow, M. (2010). Finance and growth in a bank-based economy: is it quantity or quality that matters? Journal of International Money and Finance, 29 (8), 1529-1545.

Krugman, P. (2009). The Return of Depression Economics and the Crisis of 2008. New York, NY: W. W. Norton \& Company Ltd.

Mehrling, Р. (2004). Накъде „макро” [Whither Macro?]. In M. Szenberg \& L. Ramrattan (Eds.), Нови хоризонти в икономиката [New Frontiers in Economics] (V. Bakalova, Trans.) (pp. 185-196). Sofia: Prof. Marin Drinov.

Minassian, G. (2011). Breaking the Bulgarian Economic Model. Reasons and Projections. Saarbrücken, VDM Verlag Dr. Müller GmbH \& Co. KG.

Mises, L. (2006). Marxism Unmasked: From Delusion to Destruction. New York, NY: Foundation for Economic Education.

Ray, D. (2004). Какво е новото в икономиката на развитието? [What's New in Development Economics?] In M. Szenberg \& L. Ramrattan (Eds.), Нови хоризонти в икономиката [New Frontiers in Economics] (V. Bakalova, Trans.) (pp. 247-269). Sofia: Prof. Marin Drinov.

Roubini, N., \& Mihm, S. (2010). Crisis Economics. A Crash Course in the Future of Finance. New York, NY: The Penguin Press HC.

Sariyski, G. (2008). Evaluation of the Financial Reliability of the Firm. Economic Thought Journal, 2008 (1), 26-48.
Stiglitz, J. E. (2003). Globalization and its Discontents. New York, NY: W. W. Norton \& Company.

Stiglitz, J. E. (2010a). Freefall. America, Free Markets, and the Sinking of the World Economy. New York, NY: W. W. Norton \& Company.

Stiglitz, J. E. (Ed.). (2010b). The Stiglitz Report: Reforming The International Monetary and Financial Systems in the Wake of the Global Crisis. New York, NY: The New Press.

Stiglitz, J. E., Sen, A., Fitoussi, J. P. (2010). Mismeasuring Our Lives: Why GDP Doesn't Add Up Paperback. New York, NY: New Press.

Taseva, G. (2012). Overdue Intercorporate Debts in Bulgaria. Economic Thought Journal, 2012 (3), 76-94.

Wilczyński, R. (2011). Global Financial Governance: a Perspective from the International Monetary Fund. Contemporary Economics, 5 (1), 4-16.

Wołowiec, T., \& Soboń, J. (2011). EU Integration and Harmonisation of Personal Income Taxation. Contemporary Economics, 5 (1), 36-46. 